Chapter 5

\title{
Arthropod Fauna Associated to Soybean in Croatia
}

\author{
Renata Bažok, Maja Čačija, Ana Gajger and \\ Tomislav Kos \\ Additional information is available at the end of the chapter \\ http://dx.doi.org/10.5772/54521
}

\section{Introduction}

The importance of soybean (Glycine max (L.) Merr.), as today's world leading oil and protein crop, is increasing in Croatia. As a plant species, soybean was registered for the first time in Croatia in 1876. Soybean is relatively new field crop for Croatia. It was grown for the first time in 1910 but, starting with 1970s it became important field crop [1]. In 1981, soybean was cultivated on an area of 3.381 ha. Since that time the area cultivated by soybean has increased considerably, and productivity has also risen steadily. Figure 1 presents the trends in soybean production in Croatia in the period 1993-2010 [2].

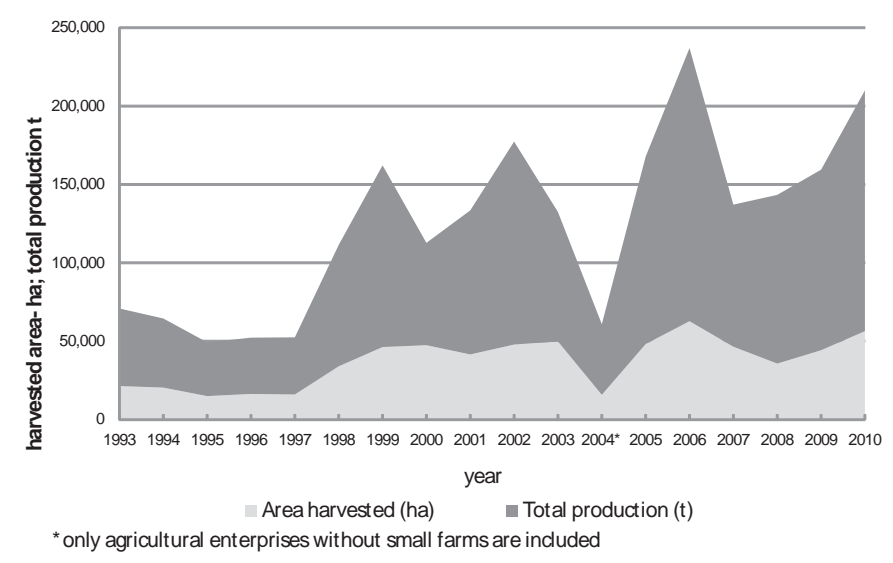

Figure 1. Harvested area and total production of soybean in Croatia, 1993-2010 
Today's the area on which soybean is cultivated in Croatia varies, depending on the year, from 30.000 to 50.000 ha. Croatian government statistics [2] show gains in average yielding ability, from 2.160 to $3.000 \mathrm{~kg} / \mathrm{ha}$, between 1993 and 2010. Comparing to data from USA [3] on the average yield between 2.197 and $2.896 \mathrm{~kg} / \mathrm{ha}$, soybean yields obtained in "regular" years in Croatia are satisfactory. The exceptions in registered yield quantity were observed in extremely dry and warm years 2000, 2003 and 2007 in which yield was between 1.380 and $1.900 \mathrm{~kg} / \mathrm{ha}$. Therefore, the main problem of soybean yielding stability is related to vulnerability of soybean production in extreme climatic conditions in which pest outbreaks influence yields negatively. Global climate changes are often discussed by numerous scientists. Besides the increase of global mean temperature [4], the incidence of the years in which extreme conditions are present vs. "regular" years is increasing. This is proved by the fact that in the period from 2000 to 2009, three years with extremely dry and warm conditions were observed. Consequently, to mitigate the negative consequences of pest outbreaks and improve profits soybean growers, in these extreme years, attempt to control the pests which can reduce crop productivity.

Comparing to weeds and diseases, in "regular years" pests are of somewhat less importance for soybean production in Croatia. In different agro-ecosystems, the arthropod fauna of soybean contains a great number of damaging species [5-8]. Soybean pests have not been investigated completely in Croatia. It was reported [8] that in the region where Croatia belongs, soybean crops are attacked by over 180 pests (150 insects and 30 species from other animal classes) among which approximately 25 pest species are the most important.

Some investigations or observations on arthropod fauna of soybean were conducted in the past on the territory of Croatia [9 - 13], and in neighboring countries [14 - 24]. Additionally, some of the species were registered recently as the pests which could cause significant yield damage on soybean [25 - 29].

The most comprehensive overview of the potential arthropod pests' fauna of soybean in Croatia is given by Maceljski [9]. This overview is a result of the literature review and author's long time work experience in entomology. On the other hand, investigations carried out by other scientists in Croatia [10 - 13] and neighboring countries [6-8, 14-24] reported on the presence or harmfulness of some additional species. In the Table 1 arthropod species that are reported as soybean pests both, in Croatia and in neighboring countries are listed.

Besides arthropod species, nematodes are established as potential pests on soybeans in Croatia [11, 12] and in neighboring countries [19]. Jelić [12] established 43 species of phytoparasitic nematodes on 18 localities distributed in east Croatia (region of Slavonia). Identified species belonged to the genera Ditylenchus Filipjev, Meloidogyne Goeldi, Paratylenchus Micoletzky, Pratylenchus Filipjev, Rotylenchus Filipjev, and Tylenchorhynchus Cobb. However significant damages caused by nematodes haven't been recorded jet. Besides mentioned pests, some authors $[8,30]$ reported that significant damage on soybean crops in Serbia could be caused by other animal species as are Cricetus cricetus L., Microtus arvalis Pallas and Lepus europaeus Pallas as well.

In regular farming practice in Croatia soybean seed is not treated with insecticides. Among the arthorpod pests, mites (Tetranychus urticae Koch and Tetranychus atlanticus $=$ T. turkestani 
Ugarov \& Nikolskii) could be controlled by the use of acaricides if their populations reach economic threshold (usually in warm and dry years). Other pest species are controlled only occasionally if pest outbreaks occur.

\begin{tabular}{|c|c|c|c|c|c|c|}
\hline Order & Suborder & Family & Species & $\begin{array}{l}\text { Literature } \\
\text { source }\end{array}$ & Croatia & $\begin{array}{l}\text { Neighboring } \\
\text { countries }\end{array}$ \\
\hline Collembola & & Smynthuridae & Sminthurus sp. Latreille 1802 & 21 & & + \\
\hline Thysanoptera & & Thripidae & $\begin{array}{l}\text { Frankliniella intonsa (Trybom } \\
\text { 1985) }\end{array}$ & 21 & & + \\
\hline \multirow[t]{18}{*}{ Hemiptera } & Heteroptera & Miridae & Lygus sp. Hahn 1833 & 9 & + & \\
\hline & & & $\begin{array}{l}\text { Lygus gemellatus (Heerrich- } \\
\text { Schaeffer 1835) }\end{array}$ & 21 & & + \\
\hline & & & $\begin{array}{l}\text { Lygus pratensis (Linneaus } \\
1758 \text { ) }\end{array}$ & 24 & & + \\
\hline & & & $\begin{array}{l}\text { Lygus rugulipennis Poppius } \\
1911\end{array}$ & 8 & & + \\
\hline & & & $\begin{array}{l}\text { Halticus apterus (Linnaeus } \\
\text { 1758) }\end{array}$ & 9 & + & \\
\hline & & & $\begin{array}{l}\text { Apolygus lucorum (Meyer- } \\
\text { Dur 1843) }\end{array}$ & 24 & & + \\
\hline & & Pentatomidae & $\begin{array}{l}\text { Dolycoris bacarrum (Linnaeus } \\
1758 \text { ) }\end{array}$ & 21,24 & & + \\
\hline & & & $\begin{array}{l}\text { Eurydema oleracea (Linnaeus } \\
\text { 1758) }\end{array}$ & 24 & & + \\
\hline & & & $\begin{array}{l}\text { Nezara viridula (Linnaeus } \\
1758 \text { ) }\end{array}$ & 9,26 & + & \\
\hline & & & Piezodorus sp. Fieber 1861 & 9 & + & \\
\hline & & Anthocoridae & Anthocoris sp. Fallen 1814 & 9 & + & \\
\hline & & & Orius niger Woolf 1811 & 6 & & + \\
\hline & & Nabidae & $\begin{array}{l}\text { Nabis (Nabis) ferus Linnaeus } \\
1758\end{array}$ & 6,9 & + & + \\
\hline & & & Nabis feroides Wagner 1967 & 6 & & + \\
\hline & & & $\begin{array}{l}\text { Nabis pseudoferus Remane } \\
1949\end{array}$ & 6 & & + \\
\hline & Homoptera & Membracidae & $\begin{array}{l}\text { Sctictocephala bisonia Koop } \\
\text { \& Yonke }\end{array}$ & $9,22,24$ & + & + \\
\hline & & & $\begin{array}{l}\text { Cicadella viridis (Linnaeus } \\
1758 \text { ) }\end{array}$ & 9 & + & \\
\hline & & Aphididae & Aphis craccivora Koch 1854 & 21 & & + \\
\hline
\end{tabular}




\begin{tabular}{|c|c|c|c|c|c|c|}
\hline Order & Suborder & Family & Species & $\begin{array}{l}\text { Literature } \\
\text { source }\end{array}$ & Croatia & $\begin{array}{c}\text { Neighboring } \\
\text { countries }\end{array}$ \\
\hline & & Diaspididae & $\begin{array}{l}\text { Lepidosaphes sp. Shimer } \\
1898\end{array}$ & 21 & & + \\
\hline \multirow[t]{11}{*}{ Coleoptera } & & Elateridae & $\begin{array}{l}\text { Agriotes ustulatus Schaller } \\
1793\end{array}$ & 15 & & \\
\hline & & & Agriotes sp. Eschscholtz 1829 & 15 & & + \\
\hline & & Scarabaeidae & $\begin{array}{l}\text { Anomala sp. Schoenherr } \\
1817\end{array}$ & 21 & & + \\
\hline & & Anobiidae & $\begin{array}{l}\text { Stegobium paniceum } \\
\text { (Linnaeus 1758) }\end{array}$ & 21 & & + \\
\hline & & Cocinelidae & $\begin{array}{l}\text { Subcocinella } \\
\text { vigintiquatuorpunctata } \\
\text { (Linnaeus 1758) }\end{array}$ & 9,21 & + & + \\
\hline & & Chrysomelidae & $\begin{array}{l}\text { Longitarsus sp. Berthold } \\
1827\end{array}$ & 9 & + & \\
\hline & & & $\begin{array}{l}\text { Phylotreta undulata } \\
\text { Kutschera } 1860\end{array}$ & 9 & + & \\
\hline & & & $\begin{array}{l}\text { Haltica oleracea Linnaeus } \\
1758\end{array}$ & 9 & + & \\
\hline & & Lathiridae & Corticaria sp. Marsham 1802 & 9 & + & \\
\hline & & Curculionidae & Phyllobius sp. Germar 1824 & 9 & + & \\
\hline & & & Sitophillus sp. Schnherr, 1838 & 9 & + & \\
\hline \multirow[t]{9}{*}{ Lepidoptera } & & Gracilariidae & $\begin{array}{l}\text { Phylonorycter insignitella } \\
\text { Zeller } 1846\end{array}$ & 24 & & + \\
\hline & & Pyralidae & $\begin{array}{l}\text { Etiella zinckenella (Treitschke } \\
\text { 1832) }\end{array}$ & $8,9,14,21$ & + & + \\
\hline & & Crambidae & Udea ferrugalis Hubner 1796 & 21 & & + \\
\hline & & Tortricidae & $\begin{array}{l}\text { Olethreutes lacunana } \\
\text { Freeman } 1941\end{array}$ & 21 & & + \\
\hline & & & $\begin{array}{l}\text { Grapholita compositella } \\
\text { Fabricius } 1775\end{array}$ & 24 & & + \\
\hline & & Lymanthridae & Orgya gonostigma L. & 21 & & + \\
\hline & & Geometridae & $\begin{array}{l}\text { Ascotis selenaria Dennis \& } \\
\text { Schiffermuller } 1775\end{array}$ & 21 & & + \\
\hline & & Nymphalidae & $\begin{array}{l}\text { Vanessa cardui Linnaeus } \\
1758\end{array}$ & $\begin{array}{c}9,20,23 \\
24,25,27 \\
28,29\end{array}$ & + & + \\
\hline & & Noctuidae & $\begin{array}{l}\text { Acronicta (Viminia) rumicis } \\
\text { (Linnaeus 1758) }\end{array}$ & 21 & & + \\
\hline
\end{tabular}




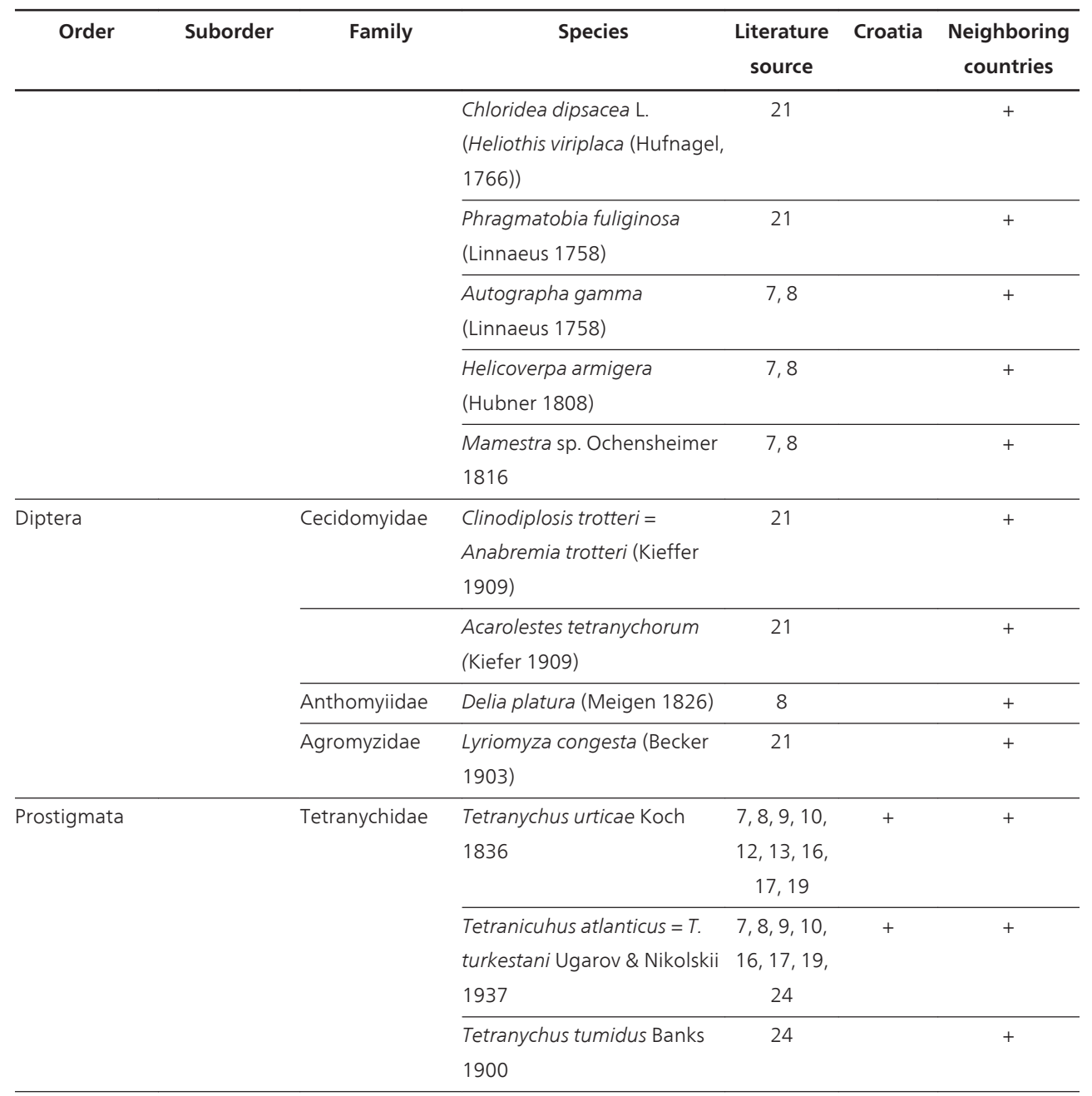

Table 1. Arthropod species established to damage soybean in Croatia and neighburing countries

In only one investigation which was carried out in Serbia [21] beneficial fauna on soybean was recorded. Only three predatory species were established, Coccinella septempunctata L. (Coleoptera: Coccinelidae), Chrysopa carnea Stephens (Neuroptera: Chrysopidae) and Acarolestes tetranychorum Kief. (Diptera: Cecidomyidae). There are no similar investigations conducted in Croatia but, out of all species listed [9] as potential members of entomofauna of soybean, two species (Anthocoris sp. Fallen and Nabis (Nabis) ferus L.) are listed as potential beneficial insects.

The subject of pest control is rarely discussed without the reference to the concept of integrated pest management (IPM). IPM is essentially a holistic approach to pest control that 
seeks to optimize the use of a combination of methods to manage whole spectrum of pests within particular cropping system. IPM relies heavily on biological controls with a perspective chemical input only as a last resort. For effective control, there needs to be an understanding of a pest's interaction with its environment. This is so called concept of "life system" which was initially conceived by Clark et al. [31] to reinforce the idea that population cannot be considered apart from the ecosystem with which it interacts. The life system consists of the pest population plus its "effective environment". Most ecological pest management concentrates on the agro-ecosystem, defined as "effective environment" at the crop level [32]. Monitoring in insect pest management can be used to determine the geographical distribution of pests, to assess the effectiveness of control measures, but in its widest sense monitoring is the process of measuring the variables required for the development and use of forecast to predict pest outbreaks [33]. Such forecasts are an important component of pest management strategies because a warning of the timing and extent of pest attack can improve the efficiency of control measures. For successful pest control according to the principles of IPM it is of great importance to have deep knowledge in harmful and beneficial arthoropods in particular agro-ecological conditions.

The study was conducted to determine the harmful and beneficial arthropod fauna during the soybean growing season, and based on their dynamic of occurrence and abundance to identify the harmful and beneficial species of greater importance for soybean production in Croatia.

\section{Materials and methods}

Research was conducted on experimental field located in Zagreb. The soybean variety Zlata (BC Institute Zagreb, Croatia) was planted on April 27 2010 on an experimental area of 162 $\mathrm{m}^{2}$. The average plant density was 630.000 plants/ha. Soybean variety Zlata belongs to the maturity group " 0 " and according to the information given by producers [34] it has a "good" tolerance to pests and diseases. In order to control weeds gyphosate (pre-sowing), metribuzin, metholachlor and clomazone (in the phase of the first trifoliate - V1, according to [35]) and bentazon (in the phase of the third trifoliate - V3) were applied.

Sweep net sampling consisted of making a set of 50 sweeps across three rows of soybeans while walking down the row [36]. A $30 \mathrm{~cm}$ diameter sweep net was used. Sampling began when soybeans were in the beginning of flowering (R1) on June $24^{\text {th }} 2010$ and continued through September $9^{\text {th }} 2010$ when plants reached physiological maturity (R7). Weekly sampling was done on the same day each week in late morning. It was performed for 12 weeks. At each sampling date four samples were collected.

Whole plant counts were conducted on 10 plants per each of four replicates. As it was proposed by Kogan and Pitre [36] randomly selected plants were initially scanned for large, often fast moving species. After the initial scan, both sides of each leaf on the plant were searched, as were petioles, axils and stems. Additionally, one leaf per plant was collected at each whole plant count date to establish mite population by leaf inspection. Therefore, four 
samples each containing 10 leaves were transported to laboratory to be examined under the stereomicroscope and all life stages of mites were counted [37]. Whole plant counts and leaf collection began one week later than sweep net sampling i.e. on July $1^{\text {st }} 2010$ and continued through September $9^{\text {th }}$ 2010. It was performed for 11 weeks.

All collected insects were identified to the family or genus and species (if possible). For identifying insects identification keys were used [38-42].

Based on the number of all individuals, cenological characteristics (dominance and frequency) of the insect orders and families (where appropriate) were determined [43].

The dominance was calculated by Balogh formula:

$\mathrm{D} 1=\frac{\mathrm{a}_{1}}{\sum \mathrm{a}_{i}} \times 100$

Where: $\mathrm{a}_{1}=$ number of identified specimens of one species;

$\Sigma_{\mathrm{a} 1}=$ total number of all collected specimens.

The frequency was calculated by Balogh formula:

$\mathrm{C}_{\mathrm{a} 1}=\frac{\mathrm{U}_{\mathrm{a} 1}}{\sum \mathrm{U}_{\mathrm{i}}} \times 100$

Where: $\mathrm{U}_{\mathrm{a} 1}=$ number of samples with identified species;

$\sum \mathrm{U}_{\mathrm{i}}=$ total number of samples.

\section{Results and discussion}

The total catch was 1357 specimens which belong to six orders: Thysanoptera, Hemiptera, Coleoptera, Lepidoptera, Diptera and Prostigmata (Table 2).

Out of 1357 specimens, only 73 individuals (5.37\%) belong to beneficial fauna (mostly predators), while all other collected specimens are herbivorous and therefore potential pests on soybean. All found beneficials belonged to predators and majority of them (70 individuals) belong to Hemiptera what confirms the statement of Ketzschmar [44] that predaceous Hemiptera are usually more abundant in soybean fields than all other insect predators combined. In earlier investigations [21] conducted in Serbia no predaceous Hemiptera have been found while more recent investigations in Serbia [6] and in Croatia [9] stated that they are present in soybean crops. All predaceous Hemiptera feed on a wide range of hosts and may extend this polyphagy to plant feeding to some extent [45]. Such plant feeding causes no damage to row crops but almost certainly has survival value for the predators by maintaining populations where prey are scarce or absent. Some of the species which belong to family Pentatomidae are also recognized as predators [45]. Since some of the individuals collected in our 
investigation were classified as family Pentatomidae but, were not identified to the species, it is possible that some of them are predaceous as well.

\begin{tabular}{|c|c|c|c|c|c|c|}
\hline \multirow[t]{4}{*}{ ORDER } & \multirow[t]{4}{*}{ FAMILY } & \multirow[t]{4}{*}{ GENUS } & \multirow[t]{4}{*}{ SPECIES } & \multicolumn{3}{|c|}{$\begin{array}{l}\text { TOTAL NUMBER OF INDIVIDUALS CAPTURED } \\
\text { BY }\end{array}$} \\
\hline & & & & SWEEP NET & WHOLE & LEAF INSPECTION \\
\hline & & & & & PLANT & \\
\hline & & & & & COUNTS & \\
\hline \multicolumn{2}{|l|}{ Thysanoptera } & * & & 52 & 12 & \\
\hline \multirow[t]{19}{*}{ Hemiptera } & Miridae & Halticus & apterus & 44 & 3 & \\
\hline & & Lygus Hahn & sp. & 4 & & \\
\hline & & 1833 & & & & \\
\hline & Nabidae & Nabis & ferus & 55 & & \\
\hline & & & Linnaeus & & & \\
\hline & & & 1758 & & & \\
\hline & Anthocoridae & * & & 3 & 8 & \\
\hline & Pentatomidae & * & & 12 & & \\
\hline & & Nezara & viridula & 472 & 181 & \\
\hline & & & Linnaeus & & & \\
\hline & & & 1758 & & & \\
\hline & & Piezodorus & sp. Fieber & 28 & & \\
\hline & & & 1861 & & & \\
\hline & Membracidae & Stictocephala & bisonia Kopp & 2 & & \\
\hline & & & \& Yonke & & & \\
\hline & & & 1977 & & & \\
\hline & Cicadellidae & Cicadella & viridis & 3 & & \\
\hline & & & Linnaeus & & & \\
\hline & & & 1758 & & & \\
\hline \multirow[t]{11}{*}{ Coleoptera } & Coccinelidae & * & & 3 & & \\
\hline & Chrysomelidae & Phyllotreta & undulata & 4 & & \\
\hline & & & Kutschera & & & \\
\hline & & & 1860 & & & \\
\hline & & Haltica & oleracea & 7 & & \\
\hline & & & Linnaeus & & & \\
\hline & & & 1758 & & & \\
\hline & & Longitarsus & sp. & 2 & 1 & \\
\hline & & Berthold 1827 & & & & \\
\hline & Latridiidae & Corticaria & sp. & 21 & & \\
\hline & & Marsham 1802 & & & & \\
\hline
\end{tabular}




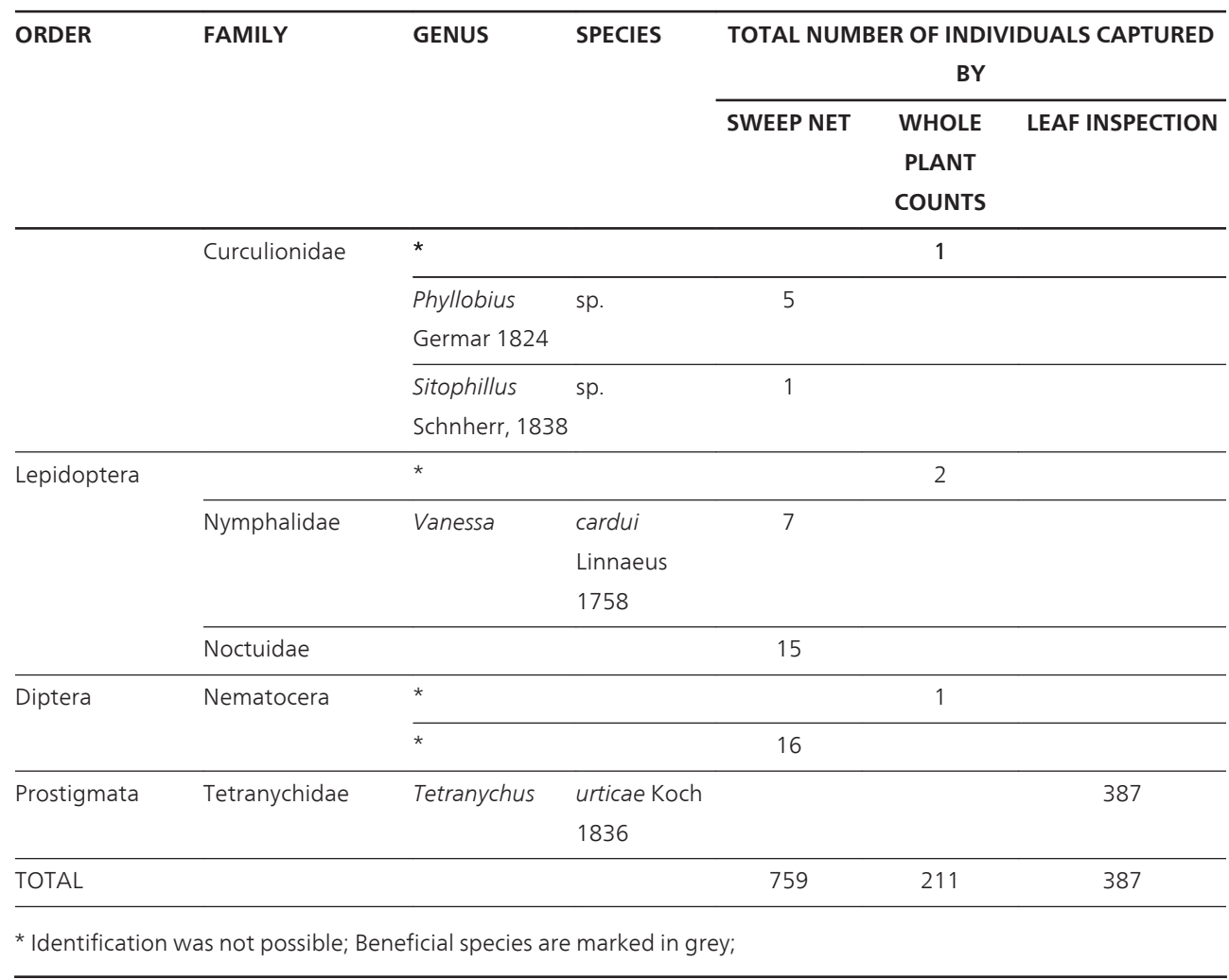

Table 2. Arthropod species established during the soybean vegetation in 2010 by three different methods

Using the entomological net, 759 individuals were collected, whereas 211 individuals were gathered by whole plant counts and 387 individuals by leaf inspection.

\subsection{Sweep net sampling}

Number of arthropod individuals collected by sweep net sampling was the highest among the three methods applied. Using these methods, species belonging to 20 different systematic categories were collected. The collected individuals belonged to five insect orders, Thysanoptera, Hemiptera, Coleoptera, Lepidoptera and Diptera. The abundance of insect orders established by sweep net sampling is shown in Figure 2.

Order Hemiptera was present in the sweep net sampling in the highest abundance $(82.48 \%)$. The same order was the most frequent. It was present in $87.5 \%$ of all samples obtained by sweep net sampling. Order Coleoptera was present in $57.5 \%$ of all samples and was designated as constant. Other orders (Thysanoptera, Lepidoptera and Diptera) were less frequent; they were present in $30-37.5 \%$ of all samples. Investigations conducted in different agro-ecosystems showed that the sweep net sampling is the most effective method to collect different 
- Thysanoptera $\square$ Hemiptera $\square$ Coleoptera $\square$ Lepidoptera $\square$ Diptera

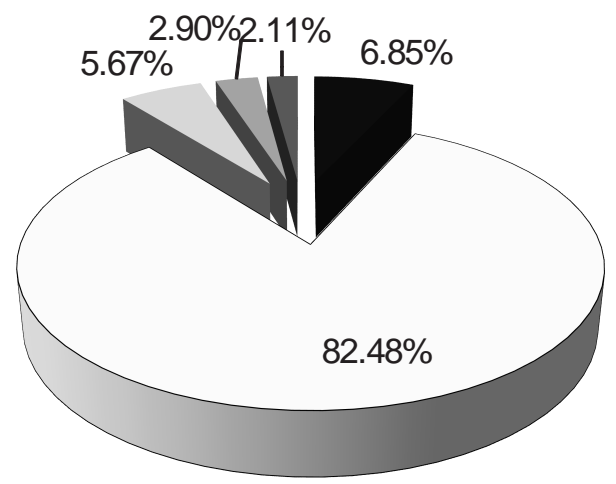

Figure 2. Abundance of insect orders collected by sweep net sampling of soybean crop, Zagreb, 2010

leaf feeding pests as are leafhoppers [46], lepidopterous larvae [46, 47], leaf feeding Coleoptera [48] and phytophagous Pentatomidae [49] as well as predaceous Hemiptera [45].

\subsection{Whole plant count}

The lowest number of individuals was established by whole plant count method. The majority of established individuals belonged to order Hemiptera. Only few Thysanoptera and Lepidoptera were established by this method. Some authors stated that this method is suitable for larvae of Lepidoptera [46, 47] and for phytophagous thryps [50]. There are no data on any damage caused by any phytophagous thrips in Croatia while Vanessa cardui L. was recorded in previous investigations as important pest.

\subsection{Leaf sampling and inspection}

The only species established by leaf inspection was T. urticae. It was proved that this method is good for establishing population of phytophagous thrips [48], whiteflies [49] and mites [35]. It is obviously that out of these three groups, only phytophagus mites were present in experimental field.

\subsection{Collected species: abundance and importance}

Sampling arthropod populations is a cornerstone of basic research on agricultural ecosystems and the principal tool for building and implementing pest management programs. The purpose of sampling is dual, it is a research method for defining the nature and dynamics of communities in agricultural ecosystems and it is also a mean for providing pest management decision. The purpose of sampling in our investigation was to get deep knowledge on pest and beneficial species present in soybean crop. Conducted investigation encompassed three most common sampling methods for investigations of soybean arthropod fauna. The 
need to encompass all three methods is confirmed later by the fact that species identified by each particular method differ. By employed methods we were able to get all relevant data on above ground arthropod fauna that could be found on soybean canopy. We did not aim to collect information on underground soybean arthropods and ground predators in soybean fields. To collect this information we should use common methods for sampling soil arthropods, soil samples and extraction [51] or pitfall trapping [48]. Some of earlier researches on soybean arthropod fauna in the region collected information on underground soybean arthropods but, no research did pay attention on ground predators in soybean field. No researches among all conducted [6-29] did pay attention to abundance and frequency of particular orders, genus or species as well, so it is not possible to compare if there are some discrepancies with the results of previous researches.

Individuals that belonged to the order Thysanoptera have been found by sweep net sampling in highest abundance than by whole plan counts, and they haven't been found by leaf inspection at all. In Serbia one phytophagous thrips species (Frankliniella intonsa Trybom) on soybean has been identified [21]. Since in our investigation thrips were not established by leaf sampling and inspection, it could be concluded that they did not feed and develop on soybean. It might be that those species are predaceous because it is reported [52] that thrips are natural enemies of different pests. Important predaceous genera of thrips are Aelothrips Haliday, Franklinothrips Back, Scolothrips Hinds, Leptothrips Hood, Karnyothrips Watson and Podothrips Hood. Within the genus Aeolothrips, the species Aeolothrips intermedius Bagnall is distributed throughout western and eastern Europe [53], the middle East and India but now it can be considered cosmopolitan [54]. Comparative tests by many authors $[53,55,56]$ using different types of prey (including various species of Thysanoptera), suggested that both the larvae and the adult females are generic predators, even though they present marked dietary preferences. In Italy [57] A. intermedius was detected in association with various different phytophagous Thysanoptera, which included T. tabaci but also frequently $F$. occidentalis on many different plant species including legume species Medicago sativa L. Predaceous thyrips belonging to the genus Aelothips are reported as important predators of T. urticae in soyben crops in north-eastern Italy [58]. Franklinothrips sp. adults and larvae are generalist predators and attack a wide variety of arthropod pests including two spotted spider mite (T. urticae) [59]. Genus Scolothrips is counting six species in Europe [60], and one of them, Scolothrips longicornis Priesner is a predator of T. urticae [61] and T. turkestani [62]. Both pest species are registered as soybean pests in Croatia. Genus Leptothrips is not present in Europe [60]. Genus Karnyothrips is counting three species in Europe [60]. Some species are reported as predators of scale insects [63]. Genus Podothrips is known as grass-living genus. It counts only two species in Europe present only in Italy and Cyprus [60]. Since identification to the species was not possible, we cannot state which species of Thysanoptera were present.

Individuals belonging to six families of the order Hemiptera were identified in our research. Four families belong to the suborder Heteroptera (so called typical bugs) and two families belong to the suborder Homoptera.

Family Miridae was presented by genus Lygus sp. Four individuals were captured. Identification to species was not possible. Species belonged to the genus Lygus were reported by 
different authors $[6,8,21,24]$ to feed on soybean crops in Bosnia and Herzegovina and Serbia as well as in Croatia [9] without causing serious damages. More numerous were individuals of Halticus apterus. This species is distributed through Mediterranean region [64]. It was reported to feed on soybean only in Croatia [9]. Other research showed that it feeds on some legume plants such as Medicago sativa L., Lotus corniculatus L. and Trifolium repens L. in Italy, and also to be able to cause damages on onions and Gallium [64]. Since it was not reported as serious pest of soybean anywhere, it should be monitored in the future but the probability for this species to become important pest of soybean is low.

Family Nabidae was represented with one species, N. ferus. The same species was previously reported in Croatia [9] and in Serbia [6]. Additionally two other species of this genus, N. feroides and N. pseudoferus, were reported in Serbia [6]. The density of N. ferus was moderate, total of 55 individuals were captured. This species was reported as common predator species in Ukraine [65]. Aphids are the principal prey insects for this species, but numerous other families are acceptable, including other bugs [65]. Because of its possible importance in soybean agro-ecosystems, the dynamic of the appearance of this species will be further analyzed.

Eleven individuals belonging to family Anthocoridae were captured in our investigation. Family Anthocoridae was previously reported in soybean in Croatia [9] and in Serbia [6]. This family is mentioned as one of the most important predaceous family of Heteroptera in soybean crops [45]. Within the family Anthocoridae, members of the genus Orius occur as predators in soybean fields all around the world [45]. The species Orius niger Woolf has been found in soybean fields in Serbia [6]. In some areas, species of the genus Anthocoris Fallen are probably also important predators in soybean [45]. Captured individuals were not identified to the species so it is not possible to discuss which genus was the most abundant in our investigations.

Among the established Hemiptera, family Pentatomidae was the most abundant. Altogether 512 individuals were found in sweep-net samples and 181 individuals by whole plant counts. The most abundant species was the southern green stink bug, Nezara viridula L. This species was reported as present in Croatia [9]. Recently the serious damages caused by this species were reported in Croatia [26]. It is not mentioned as serious pest in neighboring countries, while it was mentioned as serious threat to soybeans in Italy [58, 66]. It was reported [49] as one of the most abundant phytophagous stink bugs on soybean worldwide among of almost 40 species of stink bugs that have been found on soybean. Due to high number of captured individuals and registered damages caused by this species, it might be identified as one of the potential pests on soybean in Croatia. Therefore the dynamic of the appearance will be further analyzed. Species belonging to phytophagous genus Piezodorus were captured in lower number. Genus Piezodorus was reported as possible pest genus in Croatia [9] and in Italy [58]. The importance of the species P. guildinii Westwood is increasing in USA as well as in Brazil. This species was observed for the first time in southern Louisiana in 2000 and since 2002, it has been a significant pest of soybean [67]. At present, Eustichus heros (F.) and P. guildinii are more widespread and occur in greater numbers than $N$. viridula, and $P$. guildinii is principally responsible for the green bean syndrome observed 
in Brazilian soybean [68]. Genus Piezodorus is counting three species in Europe [60]. Twelve individuals, members of family Pentatomidae remained unidentified. It is possible that some of them are phytophagous. Also it is possible that some of them are predators because species which belong to family Pentatomidae are also recognized as predators [45].

Two families each represented with one species from the suborder Homoptera have been collected in low numbers. Stictocephala bisonia was reported to feed on soybean in Croatia [9], Serbia [21] and Bosnia and Herzegovina [24]. The second identified species was Cicadella viridis. This species was registered to feed on soybean in Croatia [9] but without significant damage. Within the USA, potato leafhopper (Empoasca fabae Harris) is the most important leafhopper species [69]. Even though aphids are recognized as a regular part of entomofauna of soybean, we did not record them. Several species of aphids are known to attack soybean crops. The most important species in North America is Aphis gyicines Matsumura [70, 71]. This species is not registered in Europe [60]. Some other species of aphids that are members of the fauna of Europe [60] and Croatia [72, 73] successfully colonize and reproduce parthenogenetically on soybean [71]: A. craccivora Koch, Aulacorthum solani (Kaltenbach) and Aphys gossypii Glover.

Out of four families of the order Coleoptera that were identified, one represents mainly predaceous species (family Coccinelidae). Some species of the family Coccinelidae are reported as the members of arthropod fauna on soybean in Croatia and Serbia [9, 21]. Species Epilachna varivestris Mulsant is known as a soybean pest in USA [48]. Three species of the phytophagous genus Epilachna are present in Europe, including Croatia [60] but only in Dalmatia where soybean cultivation is not common. Individuals from the genus Corticaria, family Latridiidae were the most numerous. Adults and larvae of this family feed on the conidia of fungi and Myxomycetes [74]. All found species from the order Coleoptera were previously listed as potential members of soybean fauna in Croatia [9] but, due to the low populations, their potential to be significant pests or predators is not very high. We did not employ any method for sampling soil dwelling insects or underground fauna. Therefore we did not collect the species which belong to families Elateridae and Scarabaeidae that are known as polyphagous soil pests that could cause damage on soybean crops [15, 21].

Only 22 individuals from order Lepidoptera were collected. Painted Lady (Vanessa cardui) was the only identified species. Other specimens were classified into the family Noctuidae. $V$. cardui was previously recorded to significantly damage soybean in Croatia $[9,25,27,29]$ and in neighboring countries [20,23]. The outbreak of this pest is periodical. Higher population could be expected in weedy soybean fields because females are attracted by pollen sources and heavy plant density [25]. There are many of species from the family of Noctuidae and from the other families, members of the order Lepidoptera which could cause the damage but, until now, serious damage in Croatia was reported only by $V$. cardui. In USA, the most important lepidopterous species are Anticarsia gemmatalis (Hubner), Pseudoplusia includens (Walker), Trichoplusia ni (Hubner), Platypena scabra F., Heliothis zea Boddie, Heliothis virescens (Fabricius) and Heliothis (=Helicoverpa) armigera (Hubner) [46, 47, 75]. Except T. ni and H. armigera, other species are not distributed in Europe [60]. H. armigera is often mentioned as one of the potentially very dangerous species. Because of its invasive nature this 
pest is currently placed on Annex I A II of Council Directive 2000/29/EC, indicating that it is considered to be relevant for the entire EU and that phytosanitary measures are required when it is found on any plants or plant products. Some countries made pest risk analyses [76]. Damages caused by this species were reported on soybeans in Vojvodina Province of Serbia and in Montenegro in the very warm summer of 2003 [77] when $85.3 \%$ of the soybean pods were injured in August. H. armigera is a serious pest on outdoor crops in Portugal and Spain, predominantly on tomato crops as well as on cottom and maize. It developed resistance to many groups of insecticides [78]. We did not find caterpillars of limabean pod borer (Etiella zinckenella Treitschke) even though this species was reported as soybean pest in Croatia [9] and in neighboring countries [6, 14, 21]. In Southern Europe and in Central and South America E. zinckenella is only damaging pod borer species in soybean.

Order Diptera was represented by 17 individuals that were not indentified to the species. The pest species from the order Diptera reported in the literature are Delia platura Meigen [6, 58], Liriomyza congesta Becker and Clinodiplosis trotteri Kief. [21]. Larvae of D. platura could cause damage on soybean seed during the emergence. Larvae of $L$. congesta are damaging leaves [21] and larvae of C. trotteri are damaging plant stem [21]. Some of Diptera species in soybean could be natural enemies, for example predaceous species Acarolestes tetranychorum feed on mites [21].

We established one species from order Prostigmata (infraclass Acari). This was the species T. urticae which was established only by leaf inspection. This species is the most important pest of soybean in the whole region $[6,8-10,13,17,19,29]$. The pest outbreaks are occurring in dry and warm years in which farmers must apply control measures. Besides T. urticae, soybean in Croatia [9] and neighboring countries [16, 17, 19] is often attacked by T. atlanticus (= turkestani). Both species have similar thermal requirements but, T. atlanticus prefers extremely dry conditions [9]. Some differences were established in their response to host plant nutrient status [79]. The development of T. urticae is positively influenced by potassium content in the plant host, while T. atlanticus is positively influenced by content of phosphorus. According to the data obtained from Meteorological and Hydrological Service of Republic of Croatia, somewhat lower temperatures and higher amount of rainfalls in July and August in 2010, comparing to the average were recorded. That could cause the absence of T. atlanticus in experimental field and relatively low population of T. urticae.

The dominance indices of the insect orders established in total capture are shown in Figure 3.

In total catch the eudominant orders were Hemiptera (60.46\%) and Acarina (28.6\%), while subdominant were orders Thysanoptera $(4.73 \%)$, Coleoptera $(3.33 \%)$, Lepidoptera $(1.63 \%)$ and Diptera (1.26\%).

\subsection{Most important phytophagous species}

The significant feeding on soybean was established by two species, $N$. viridula and T. urticae. Therefore we will further analyze their appearance with the respect of their life cycle and possible damages that they can cause.

The dynamic of the appearance of N. viridula is shown in Figure 4. 

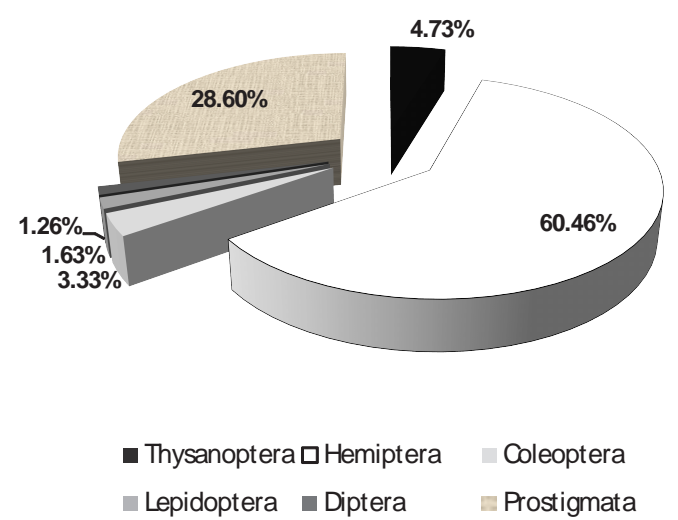

Figure 3. The dominance indices of arthropod orders established in the total capture of arthropod species on soybean in Croatia in 2010

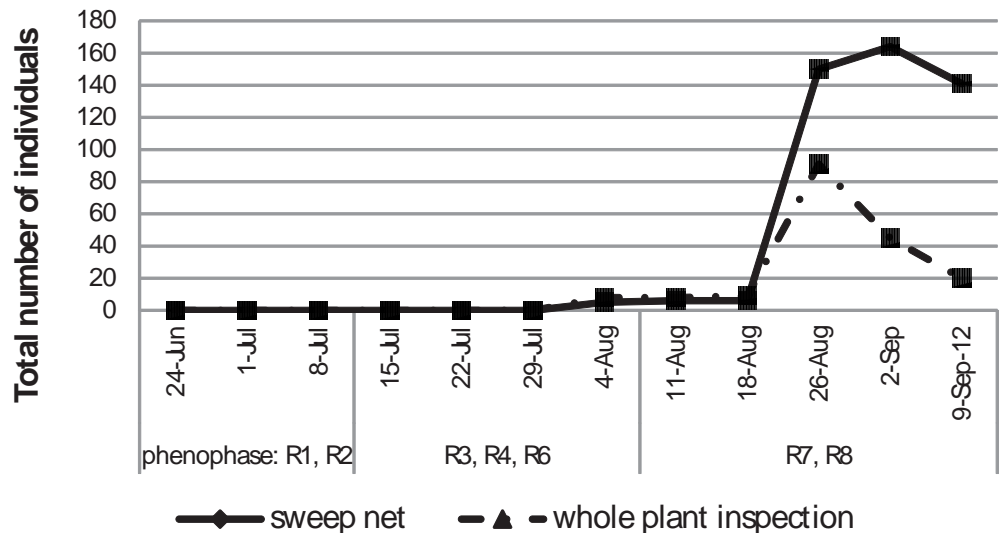

Figure 4. The dynamic of the appearance of Nezara viridula (L.) on soybeans in Croatia in 2010 established by two sampling methods

The southern green stink bug, $N$. viridula, is one of the most economically important soybean pests [80]. It has a worldwide distribution, occurring throughout the tropical and subtropical regions of Europa, Asia, Africa and America [49]. This pest is in constant expansion as a consequence of the increased acreage for soybean production, particularly in South America [80]. This pentatomid is highly polyphagous, attacking more than 145 species of plants (including cultivated and uncultivated species) within 32 families [49]. Life cycle of the southern green stink bug has been studied by number of authors in different parts of the world [81-85]. The biology of this pest has not been studied in Croatia jet but, some data were presented by different authors [26, 29]. From literature it is known [49] that southern green stink bug, like most pentatomids, overwinters in the adult stage under different objects that offer protection (litter, bark etc.). In the northern hemisphere [49] overwintering 
adults emerge in March and first generation develops on clover. The total developmental time from eggs to adults lasts between 23 days [82] and 49 days [81]. In USA, it develops 3-5 generations per year, depending on the climate. The 3rd, 4th and 5th generations attack soybean. We found it on soybean when soybeans began to mature, in August and onward what corresponds with the data presented by Todd and Herzog [49]. Probably the first two generations developed on some other plants. Stink bugs feed primarily on the seeds of soybean. Feeding results with puncture marks on the seed coat, deformation of the seed coats and reduced seed weight and size. Adults live longer, approximately 30 to 50 days [81, 82] and they cause more damage than nymphs [86]. Croatian authors [26] proposed economic threshold of $1 \mathrm{bug} / 30 \mathrm{~m}$ of soybean row or 8-10 bugs/10 sweep nets what seems to be too low. It is important to point out that the threshold depends on the period when insects occur. Early infestation causes more damage than late infestation [86]. Late in the season high infestation level of 2 bugs $/ \mathrm{m}^{2}$ will not result with the damage [86]. In our investigation we established infestation of 2 bugs/plant by whole plant count method and 4-5 bugs/10 sweep nets without seeing any damage on the yield. The appearance of $N$. viridula was in literature [26] connected with higher temperatures and drought, what was not the case in our investigation. Generally, in other countries the southern green stink bug is controlled with non-selective insecticides, which belong to carbamates, the organophosphate group, or the cyclodiene group, such as endosulfan or to pyrethroids [80]. Some of the mentioned insecticides are banned in Croatia and others are not allowed for that purpose. In the case of pest outbreak farmers do not have any available option to control this pest.

The second species which was recorded in high population density was T. urticae. The infestation with T. urticae started somewhat earlier that the attack of N. viridula. The dynamic of the appearance of T. urticae is shown in Figure 5.

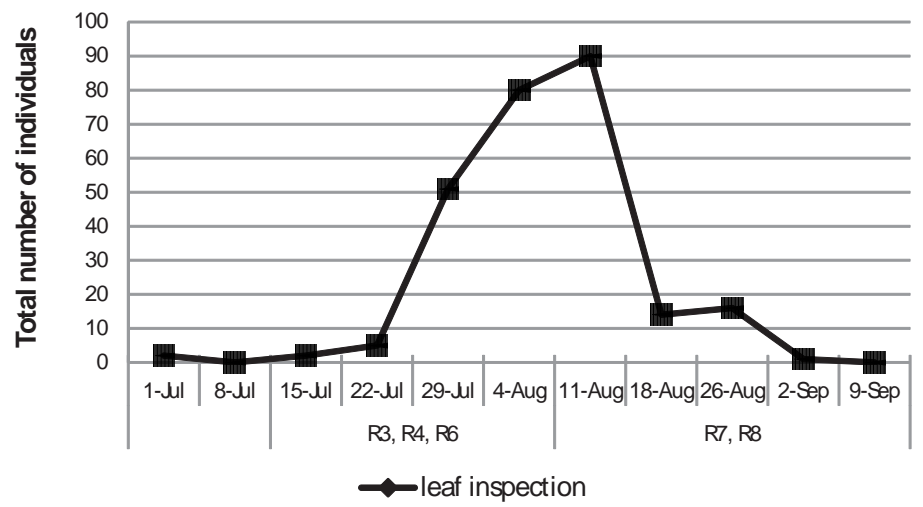

Figure 5. The dynamic of the appearance of Tetranychus urticae on soybeans in Croatia in 2010 
The maximal infestation of T. urticae was recorded on August $11^{\text {th }}$ and it was 2.25 mites/leaf. This infestation is considered as very weak to weak infestation [87]. After that date, the number of mites significantly decreased without the use of acaricides. The reason of the decrease of the population is the period in August in which strong rain occurred. Strong rain probably caused washing up the spider mites from the leaves as it was mentioned by some authors $[29,87]$. T. urticae injure soybean by feeding on the green foliage and pods. By their needle-like chelicerate mouthparts that are used to puncture individual plant tissue cells and consume the entire cytoplasmic contents, they are leaving and empty irreversible damaged cell. The presence of numerous empty cells results in the yellow or brown spots on mite-injured leaves. Extensive feeding by large numbers of mites causes the leaves to appear yellow or brown [37]. Complete defoliation due to mite feeding can reduce pod set and seed yield. Under the favorable conditions mites have very short developmental time, between 8-20 days [9]. That enables them to develop several generations in a very short time and to increase population up to the economic threshold very fast. Therefore permanent monitoring of the pest population is needed. No acaricides are allowed for the control of T. urticae in soybean crops at the moment in Croatia. Even though there are some mite resistant cultivars in USA [88], they are not registered in Croatia.

\subsection{Most important zoophagus species}

Total of 73 predaceous species are collected in the investigation. Family Nabidae was represented by one specius, N. ferus. Members of the family Nabidae are confirmed predators of different kind of insects [89]. Most types of insect prey of nabids are plant-feeding species, but nabids sometimes attack predaceous insects, including members of their own species. The polyphagous feeding habits of the nabids make them less effective than species-specific predators against specific prey species [89]. Altogether 55 individuals of $N$. ferus were counted. The dynamic of the appearance of N. ferus is shown in Figure 6.

Nabis ferus is a common, widespread species in the Palearctic region [89]. It was reported as predatory species on Trialeurodes vaporariorum Westwood [90], Oulema melanopus L. [91], Sitobion avenae F. [92] and other aphid species [65], N. viridula [93] and leafhoppers in all stages [89]. Species N. ferus overwinters in the adult stage [65]. Adults emerge from the soil and migrate to field of various crops in April and May according to the weather. They mate, lay eggs and the nymphs appear between late May and June and are present until July [65]. There is a second generation with nymphs in July-August and adults in August-October. The dynamic of the appearance of $N$. ferus in experimental field corresponds with the data on life cycle of this species [65]. In mid-late July we collected adults of the first generation and nymphs were collected in August. Kereši [94] stated that zoophagous Nabis species develop one generation per year in soybeans. She mentioned adult appearance at the end of July and maximal larval appearance at the end of August. It remains unknown in which crop species is developing the first generation. Due to its preference to prey aphids which are abundant in wheat fields, it could be that the first generation is developing in wheat fields. The experimental field in our investigation was surrounded by wheat fields what could influence high population of $N$. ferus. 


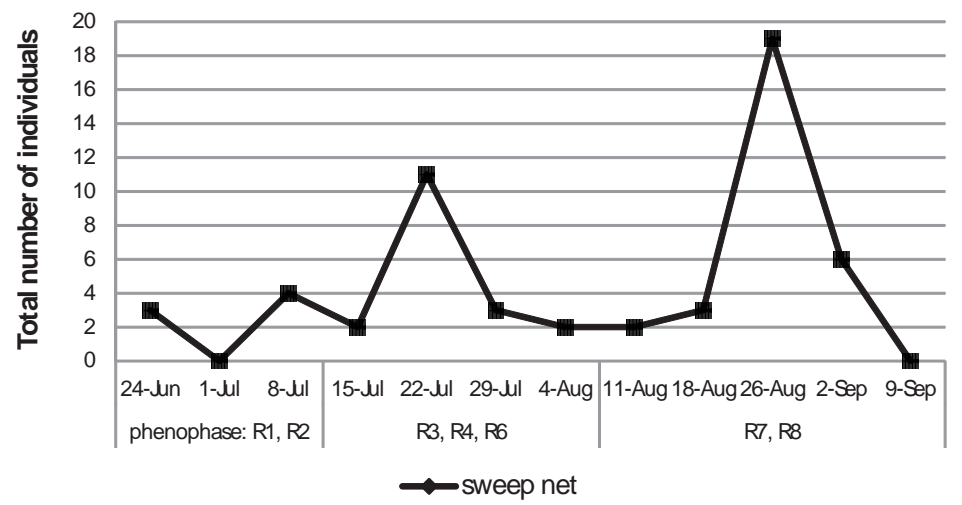

Figure 6. The dynamic of the appearance of Nabis ferus on soybeans in Croatia in 2010

\section{Conclusions}

Literature reports that soybean crops in the region where Croatia belongs (Croatia, Hungary, Serbia, Romania, Bulgaria and Bosnia and Herzegovina) are attacked by over 180 pests (150 insects and 30 species from other animal classes). However, by literature review from Croatia, Serbia and Bosnia and Herzegovina we established that 52 species (or genus) of arthropods are reported to be associated with soybean crops. Out of these 52 species, seven species are zoophagous, 44 species are phytophagous and one species is myceliophagous. Additionally, we have found data on 43 species of phytoparasitic nematodes that can be find in soybean fields but without causing significant damages and literature also reports on three species of rodents that could cause significant damage on soybean fields.

In our investigations the number of established species was lower than the number obtained by literature review. Total of 1357 individuals were collected and classified into the five orders from the class of Insects and one order from the class of Arachnida (infraclass Acari). 1232 individuals were classified in 15 species or genus, 58 individuals were classified into the six families while 67 individuals were classified into the orders. Phytophagous arthropods were more abundant than zoophagous. The ratio between phytophagous and zoophagous specimens was $94.63 \%: 5.37 \%$.

Based on the results of the literature review and of the research conducted, it could be concluded that significance of the arthropod pest fauna connected with soybean has changed over the time. Nowadays, soybean production in Croatia could be endangered by four phytophagous arthropod species: N. viridula L., V. cardui L., T. urticae and T. turkestani.

$N$. viridula is attacking soybean pods and seed causing the loss in yield quantity and quality. The early infestation is very dangerous. The population of this pest has been increasing in the past few years. This could be connected with the increase of soybean cultivation area. Obtained results indicate that the increase in pest population has occurred recently and that 
one existing species became significant pest of soybean. The life cycle of this pest as well as other issues related to sampling procedure, economic threshold and control possibilities have not been studied jet in Croatian agro-ecological conditions. In the future, investigations should be carried out with the aim to collect more data on this pest and to be able to implement IPM principles in its control.

$V$. cardui is causing defoliation of the soybean plants. As periodical pest it appears from time to time in certain areas causing significant damage. Sampling procedure for this pest is established but, research should be conducted in order to determine economic threshold and the efficacy of environmentally acceptable insecticides (B.t.k., spinosad, neem, IGRs, avermectins).

Phytophagous mites, T. urticae and T. turkestani as soybean pests are well known to Croatian farmers. Due to their feeding on soybean leaves they are causing defoliation. Their infestation is related to the climatic condition. In warm and dry years these pests cause more severe damage than in "normal" years. Sampling procedure for these pests is established but, due to the lack of registered acaricides, their control is not possible. The future research should be focused on finding appropriate ecologically acceptable acaricide for the control of this pest.

The critical period for the infestation by all four species is from flowering through maturity in which period all four pests should be monitored and sampled on a regularly basis in order to ensure the proper information about the need for control measure.

Some other pests that were found in our investigation are capable of becoming key pests if environmental conditions and population of their natural control agents are disrupted by unnecessary application of insecticides. One of these species belongs to Piezodorus sp. which is world widely recognized as very important soybean pest. Thus the future systematic and intensive study of the arthropod fauna associated with soybean in Croatia has to be continued. It will allow us to monitor the changes in the pest population and to prepare strategies for the control of the new pests that could arise over the time.

The main zoophagous species found on soybeans was Nabis ferus. The role of this species in soybean ecosystems, including its varying feeding strategies, needs much additional attention.

\section{Acknowledgements}

We thank Prof. Hrvoje Šarčević for providing us adequate experimental field conditions.

\section{Author details}

Renata Bažok, Maja Čačija, Ana Gajger and Tomislav Kos

*Address all correspondence to: rbazok@agr.hr

University of Zagreb, Faculty of Agriculture, Zagreb, Croatia 


\section{References}

[1] Vratarić M, Sudarić A. Tehnologija proizvodnje soje. Osijek: Poljoprivredni institut Osijek; 2007.

[2] Statistical Yearbook of the Republic of Croatia 2011. http://www.dzs.hr/Hrv_Eng/ ljetopis/2011/SLJH2011.pdf (accessed 15 June 2012)

[3] Wilson R. Soybean: Market driven research needs. In: G. Stacey (ed.) Genetics and Genomics of Soybean. New York: Springer Science+Business Media, LLC 2008. 3-15.

[4] Solomon S, Qin D, Manning M, Chen Z, Marquis M, Averyt KB, Tignor M, Miller HL (eds) (2007) Climate change 2007: the physical science basis. In: Contribution to working group I to the fourth assessment report of the intergovernmental panel on climate change. Cambridge University Press, chap 3 and 11

[5] Higley LG, Boethel DJ. Handbook of Soybean Insect Pests. Lanham, MD: Entomological Society of America; 1994.

[6] Kereši T, Sekulić R, Čamprag D. Important insect pests in soyabean fields. Biljni Lekar (Plant Doctor) 2008;36(3-4) 259-272.

[7] Kereši T. Bug fauna (Heteroptera) on winter wheat and soybean dependent on cropping system. PhD thesis. University of Novi Sad; 1999.

[8] Čamprag D. Harmful fauna in soybean fields and integral pest management. Biljni Lekar (Plant Doctor) 2008;36(3-4) 240-246.

[9] Maceljski M. Poljoprivredna entomologija. Čakovec: Zrinski; 2002.

[10] Dimitrijević M, Valenčić Lj, Jurković D, Ivezić M, Kondić Đ. Bolesti i štetnici važnijih ratarskih kultura na području stočne Slavonije i Baranje. Poljoprivredne aktualnosti 1985; 22(1-2) 203-223.

[11] Jelić A. Proučavanje fitoparazitskih nematoda biljaka za proizvodnju ulja na području Slavonije i Baranje sa posebnim osvrtom na soju. PhD thesis, University of Josip Juraj Strossmayer Osijek; 1989.

[12] Nikolić M. Proizvodnja i zaštita soje na društvenim površinama SOUR-a PIK „Vinkovci“ u 1983. Godini. Glasnik zaštite bilja 1984; 2 50-52.

[13] Pagliarini N. Rezultati ispitivanja efikasnosti nekih akaricida protiv T. urticae Koch. na soji u vegetaciji, In: Zbornik radova: Prvo jugoslovensko savetovanje o primeni pesticida u zaštiti bilja, 19-23 November 1979, Kupari, 1: 241-250.

[14] Atanasov P. Sojin moljac (Etiella zinckenella Tr.). Biljna zaštita 1964; 3 50-51.

[15] Čamprag D, Đurkić J, Sekulić R, Kereši T, Almaši R, Thalji R. Brojnost larvi Elateridae (Coleoptera) na raznim poljoprivrednim kulturama na području Vojvodine. Zaštita bilja (Plant Protection) 1985; 36(4) 399-404. 
[16] Đurkić J. Pojava Tetranychus atlanticus Mc. Gregor štetočine poljoprivrednih kultura u Vojvodini u 1956. godini, Zaštita bilja, (1956): 7(1): 67-70.

[17] Đurkić J, Srečković R, Sabadin T. Zapažanja o pojavi grinje na soji u 1976. godini. Suvremena poljoprivreda 1977; 5-6 45-57.

[18] Klindić O. Proučavanje nematoda prouzrokovača pjegavosti korjena - Pratylenchus spp., Zaštita bilja 1967; 18(1) 133-142.

[19] Ratajac R, Rajković D. Praćenje dinamike populacije grinja na soji u nekim lokalitetima SAP Vojvodine. Glasnik zaštite bilja 1976; 6 191-197.

[20] Sekulić R, Thalji R, Kereši, T. Prilog proučavanju ishrane gusenica i suzbijanja stričkovog šarenjaka (Pyrameis cardui L.) na soji i boraniji. Agronomski Glasnik 1983; 1 57-63.

[21] Simova-Tošić D, Vuković M, Plazinić V, Mihajlović Lj. Pojava i identifikacija najznačajnijih štetnih insekata soje u SR Srbiji. Zaštita bilja 1988; 39(1) 17-24.

[22] Tešić T. Rogati cvrčak (C. bubalus) u Srbiji. Zaštita bilja 1964; 15(6) 593-665.

[23] Vaclav V, Batinica J. Stričkov šarenjak kao štetočina soje. Poljoprivredni pregled 1962; 11(12): 408-410.

[24] Vaclav V, Radman Lj, Batinica J, Ristanović M, Dimić N, Numić R, Beš A. Prilog poznavanju bolesti i štetočinja soje na proizvodnim površinama Bosne. Zaštita bilja 1970; 21(109) 229-236.

[25] Bažok R, Ljikar K. Stričkov šarenjak - malo poznati štetnik soje. Glasilo biljne zaštite 2007; 8(1) 44-46.

[26] Majić I, Ivezić M, Raspudić E, Vratarić M, Sudarić A, Sarajlić A, Matoša M. Pojava stjenica na soji u Osijeku. Glasilo biljne zaštite 2010; 11(1-2/dodatak) 51-51.

[27] Raspudić E; Ivezić M, Ladocki Z, Pančić S, Brmež M. Stričkov šarenjak - opasnost za soju. Glasilo biljne zaštite 2007; 8(1-dodatak) 12-12

[28] Vratarić M, Sudarić A. Soja Glycine max (L.) Merr. Osijek: Poljoprivredni institut Osijek 2008.

[29] Vratarić M, Sudarić A. Važnije bolesti i štetnici na soji u Republici Hrvatskoj. Glasnik zaštite bilja 2009;36(6) 6-23.

[30] Sekulić R, Kereši T. Major pests of soybean- mites and rodents. Biljni Lekar (Plant Doctor) 2008; 36(3-4) 247-258.

[31] Clark LR, Geier PW, Hughes RD, Morris RF. The Ecology of Insect Populations in Theory and Practice. New York: Chapman \& Hall. 1967.

[32] Altieri MA.. Biodiversity and Pest Management in Agroecosystems. Binghamton, NY: Food Products Press; 1994. 
[33] Conway GR, Strategic models. In: Conway GR. (ed) Pest and Pathogen Control: Strategic, Tactical and Policy Models. New York: John Willey \& Sons; 1984. p15-28.

[34] Bc Institut d.d. Zagreb http://www.bc-institut.hr/s_zlata.htm (accessed 20 June 2012)

[35] Iowa State University- Soybean Extension and Research Program http://extension.agron.iastate.edu/soybean/production_growthstages.html (accesed 20 June 2012)

[36] Kogan, M., Pitre H.N. Jr. General Sampling Methods for Above-Ground Populations of Soybean Arthropods. In: Kogan, M., Herzog, D.C.(eds) Sampling Methods in Soybean Entomology. New York: Springer; 1980. p30-60.

[37] Poe, S.L. Sampling Mites on Soybean. In: Kogan, M., Herzog, D.C.(eds) Sampling Methods in Soybean Entomology. New York: Springer; 1980. p312-323.

[38] Schmidt, L: Tablice za determinaciju insekata. Zagreb: Sveučilišna naklada Liber; 1972.

[39] Villiers, A. Atlas des Hémiptères de France, I Hétéroptères Gynocérates: 108. Paris: Editions N. Boubee; 1951.

[40] Auber, L. Atlas des Coléoptères de France I, Belgique, Suisse. Paris: Editions N. Boubée; 1965.

[41] Bechyně, J. Welcher Käfer ist das? Kosmos-Naturfuhrer, Stuttgart: Balogh Scientific Books; 1974.

[42] Harde, K.W., Severa, F. Der Kosmos Käferführer . Kosmos-Naturfuhrer, Stuttgart: Balogh Scientific Books; 1984.

[43] Balarin I. Fauna Heteroptera na krmnim leguminozama i prirodnim livadama u SR Hrvatskoj. Doktorska disertacija, Zagreb: Agronomski fakultet. 1974.

[44] Kretzschmar GP. Soybean insects in Minnesota with special reference to sampling techniques. Journal of Economic Entomology 1948; 41 586-591.

[45] Irwin ME, Shepard M. Sampling Predaceous Hemiptera on Soybean. In: Kogan, M., Herzog, D.C.(eds) Sampling Methods in Soybean Entomology. New York: Springer; 1980. p505-531.

[46] Pedigo LP. Sampling Green Cloverworm on Soybean. In: Kogan, M., Herzog, D.C. (eds) Sampling Methods in Soybean Entomology. New York: Springer; 1980. p169-186.

[47] Herzog DC. Sampling Soybean Looper on Soybean. In: Kogan, M., Herzog, D.C.(eds) Sampling Methods in Soybean Entomology. New York: Springer; 1980. p141-168.

[48] Shelton MD, Edwards CR. Effects of Weeds on the Diversity and Abundance of Insects in Soybeans. Environmental Entomology 1983; 12(2) 266-298. 
[49] Todd JW, Herzog DC. Sampling Phytophagous Pentatomidae on Soybean. In: Kogan, M., Herzog, D.C.(eds) Sampling Methods in Soybean Entomology. New York: Springer; 1980. p438-478.

[50] Irwin ME, Yaergan KV. Sampling Phytophagous Thrips on Soybean. In: Kogan, M., Herzog, D.C.(eds) Sampling Methods in Soybean Entomology. New York: Springer; 1980. p283-304.

[51] Eastman CE. Sampling Phytophagous Underground Soybean Arthropods. In: Kogan, M., Herzog, D.C.(eds) Sampling Methods in Soybean Entomology. New York: Springer; 1980. p327-354.

[52] Lewis T. Thrips, their biology, ecology and economic importance. London: Academic Press; 1973.

[53] Bournier A, Lacasa A, Pivot Y, Biologie d'un Thrips prédateur Aeolothrips intermedius (Thys.: Aeolothripidae). Entomophaga 1978; 23 (4) 403-410.

[54] Riudavates J. Predators of Frankliniella occidentalis (Perg.) and Thrips tabaci Lind.: a review. Wageningen Agricultural University Papers 1995;95(1) 43-87.

[55] Bournier, A., Lacasa, A., Pivot, Y. Régime alimentaire d un Thrips prédateur Aeolothrips intermedius (Thys.: Aeolothripidae). Entomophaga 1979;24(4) 353-361.

[56] Lacasa, A., Bournier, A., Pivot, Y. Influencia de la temperatura sobre la biologia de un trips depredador Aeolothrips intermedius Barnall (Thys: Aeolothripidae).- Anales del Instituto Nacional de Investigaciones Agrarias, Agricola. 1982;20 87-98.

[57] Conti B. Notes on the presence of Aeolothrips intermedius in northwestern Tuscany and on its development under laboratory conditions. Bulletin of Insectology 2009;62(1) 107-112.

[58] Zandigiacomo P. Pest found in soybean crops in north-eastern Italy. Informatore Agrario 1992;48(7) 57-59.

[59] Hoddle MS, Robinson L, Drescher K, Jones J. Developmental and Reproductive Biology of a Predatory Franklinothrips sp. (Thysanoptera: Aeolothripidae). Biological Control 2000;18 27-38.

[60] Fauna Europea. http://www.faunaeur.org/ (accessed 24 June 2012)

[61] Pakyari H, Fathipour Y, Rezapanah M, Kamali K. Temperature-dependent functional response of Scolothrips longicornis (Thysanoptera: Thripidae) preying on Tetranychus urticae. Journal of Asia-Pacific Entomology 2009; 12(1) 23-26.

[62] Gheibi M, Hesami S. Life Table and Reproductive Table Parameters of Scolothrips longicornis (Thysanoptera: Thripidae) as a Predator of Two-Spotted Spider Mite, Tetranychus Turkestani (Acari: Tetranychidae). World Academy of Science, Engineering and Technology 2011;60 262-264. 
[63] Pitkin BR. A revision of the Indian species of Haplothrips and related genera (Thysanoptera: Phlaeothripidae). Bulletin of the British Museum of National History, Entomology 1976;34 223-280.

[64] Limonta L, Dioli P, Bonomelli N. Heteroptera on flowering spontaneous herbs in differently managed orchards. Bollettino di Zoologia agraria e di Bachicoltura 2004;Ser. II;36 (3) 355-366.

[65] Puchkov AV. Particulars of the biology of predacious Nabis spp. Zashchita Rastenii $1980 ; 8$ 1-44.

[66] Giorgi R. The defence of soybean: control of the principal diseases and insects. Terra e Sole 1992;47(596) 231-234.

[67] Baur ME, Sosa-Gomez DR, Ottea j, Leonard BJ, Corso IC, Da Silva JJ, Temple J, Boethel DJ. Susceptibility to Insecticides Used for Control of Piezodorus guildinii (Heteroptera: Pentatomidae) in the United States and Brazil. Journal of Economic Entomology 2010;103(3) 869-876.

[68] Sosa-Gomez, DR, Moscardi F. Different foliar retention in soyabean caused by stink bugs (Heteroptera: Pentatomidae). Anais da Sociedade Entomologica do Brasil 1995; 24(2) 401-404.

[69] Helm CG, Kogan M, Hill BG. Sampling Lefhoppers on Soybean. In: Kogan, M., Herzog, D.C.(eds) Sampling Methods in Soybean Entomology. New York: Springer; 1980. p260-282.

[70] Ragsdale DW, Landis DA, Brodeur J, Heimpel GE, Desneux N. Ecology and Management of the Soybean Aphid in North America. Annual Review of Entomology 2011;56 375-399.

[71] Irwin ME. Sampling Aphids in Soybean Fields. In: Kogan, M., Herzog, D.C.(eds) Sampling Methods in Soybean Entomology. New York: Springer; 1980. p239-259.

[72] Igrc Barčić J. Lisne uši. In: Maceljski M. (ed) Poljoprivredna entomologija. Čakovec: Zrinski; 2002. p74-126.

[73] Gotlin Čuljak T, Igrc Barčić J, Bažok R, Grubišić D. Aphid fauna (Hemiptera: Aphidoidea) in Croatia. Entomologia Croatica 2006; 9(1-2) 57-69.

[74] Andrews FG. Latridiidae Erichson 1842. In: Arnett RH Jr, Thomas MC. (eds) American Beetles Plyphaga: Scarabaeoidea through Curculionoidea. Boca Ratton:CRC; 2002. p.395-398

[75] Hillhouse TL, Pitre HN. Comparison of Sampling Techniques to Obtain Measurements of Insect Populations on Soybeans. Journal of Economic Entomology 1974;67(3) 411-414.

[76] Lammers JW, MacLeod A. Report of a Pest Risk Analysis Helicoverpa armigera (Hübner, 1808). Plant Protection Service (NL) and Central Science Laboratory (UK) 2007. 
http://www.fera.defra.gov.uk/plants/plantHealth/pestsDiseases/documents/helicoverpa.pdf (accessed 24 June 2012)

[77] Sekulic R, Kereši T, Masirevic S, Vajgand D, Radojcic S. Incidence and damage of cotton bollworm (Helicoverpa armigera Hbn.) in Vojvodina Province in 2003. Biljni Lekar (Plant Doctor) 2004;32(2) 113-124.

[78] Torres Vila L M, Rodriguez Molina MC, Lacasa Plasencia A, Bielza Lino P, Rodriguez del Rincon A. Pyrethroid resistance of Helicoverpa armigera in Spain: current status and agroecological perspective. Agriculture Ecosystems and Environment 2002;93 55-66.

[79] Cannon WN, Connel WA. Populations of Tetranychus atlanticus McG. (Acarina: Tetranychidae) on soybean supplied with various levels of nithrogen, phosphorus, and potassium. Entomologia Experimentalis et Applicata 1965; 8 153-161.

[80] Werdin Gonzalez JO, Gutierrez MM, Murray AP, Ferrero AA. Composition and biological activity of essential oils from Labiatae against Nezara viridula (Hemiptera: Pentatomidae) soybean pest. Pest Management Science 2011; 67 948-955

[81] Werdin Gonzalez JO, Ferrero AA. Table of life and fecundity by Nezara viridula var. smaragdula (Hemiptera: Pentatomidae) feed on Phaseolus vulgaris L. (Fabaceae) fruits. IDESIA 2008; 26(1) 9-13.

[82] Bharathimeena T, Sudharma K. Biological studies on the southern green stink bug, Nezara viridula (L.) and the smaller stink bug Piezedorus rubrofasciatus (F.) (Pentatomidae: Hemiptera) infesting vegetable cowpea. Pest Management in Horticultural Ecosystems 2008; 14(1) 30-36.

[83] DerChien C, ChingChung C. Life history of Nezara viridula Linnaeus and its population fluctuations on different crops. Bulletin of Taichung District Agricultural Improvement Station 1997; 55 51-59.

[84] Mukopadhyay B, Roychoudhury N. Biology of green stink bug Nezara viridula. Environment and Ecology 1987; 5(2) 325-327.

[85] Cividanes FJ, Parra JRP. Biology of soybean pests with different temperatures and thermal requirements. I. Nezara viridula (L.) (Hemiptera: Pentatomidae). Anais da Sociedade Entomologica de Brasil 1994; 23(2) 243-250.

[86] Miller LA, Rose HA, McDonald FJD. The effect of damage by the green vegetable bug Nezara viridula (L.) on yield quality of soybeans. Journal of Australian Entomological Society 1977; 16(4) 421-246.

[87] Dobrinčić R. Neki štetnici soje. Glasnik zaštite bilja 1999; 4 184-187.

[88] Hildebrand D F, Rodriguez JG, Brown GC, Luu KT, Volden CS. Peroxidative Responses of Leaves in Two Soybean Genotypes Injured by Twospotted Spider Mites (Acari: Tetranychidae). Journal of Economic Entomology 1996; 79(6)1459-1465.

[89] Lattin JD. Bionomics of the Nabidae. Annual Review of Entomology 1989; 34 383-400. 
[90] Perić P, Marčić D, Stamenkvić S. Natural enemies of whitefly (Trialeurodes vaporariorum Westwood) in Serbia. Acta Horticulturae 2009; 830 539-544.

[91] Popov C, Malschi D, Vilau F, Stoica V. Insect pest management of Lema melanopa in Romania. Romanian Agricultural Research 2005; 22 47-51.

[92] Piotrowska E. Introductory studies on some food requirements of Nabis ferus L. and Nabis pseudoferus Rem. (Heteroptera: Nabidae) on cereals. Roczniki Nauk Rolniczych (Ochrona Rastlin) 1982; 12(1-2)47-56.

[93] Hokyo N, Kiritani K. Two species of egg parasites as contemporaneous mortality factors int he egg population of the southern green stink bug, Nezara viridula. Japanese Journal of Applied Entomology and Zoology 1963; 7(3)214-227.

[94] Kereši T. The Heteroptera fauna on soybeans in Bačka. Zaštita Bilja 1993; 44(3)189-195. 